\title{
Küresel Gıda Güvencesinin İzlenmesi ve Haritalanması Üzerine Bir Değerlendirme
}

\section{Gökçe KOÇ ${ }^{* 1}$, Ayşe UZMAY ${ }^{1}$ (D)}

\section{${ }^{1}$ Ege Üniversitesi, Ziraat Fakültesi, Tarım Ekonomisi Bölümü, Bornova-izmir}

Öz: Gıda güvencesinin sağlanması, küresel hedeflerin başında gelmektedir. Mevcut durumun ortaya konması, politikalar oluşturularak ulusal ve uluslararası küresel hedeflere ulaşılabilmesi açısından, gıda güvencesinin tam ve doğru bir şekilde izlenmesi ve haritalanması son derece önemlidir. Son dönemde uluslararası organizasyonlar, ulusal kurum ve kuruluşlar, gıda güvencesinde mevcut durumun ortaya konması amacıyla ölçütler oluşturmakta ve bilgi ağları ile izlenmesini ve haritalanmasını hedeflemektedir. Ancak, küresel olarak kabul gören, güvenilir bir standart henüz oluşturulamamıştır ve tartışmalar devam etmektedir. Bu kapsamda, bu çalışmanın üç temel amacı bulunmaktadır; ilki gıda güvencesinin ölçütlerine göre kullanılan yöntemlerin sınıflandırılması, ikincisi her bir ölçüt için değerlendirmelerin ortaya konması, bilimsel araştırma sonuçlarının tartışılması ve son olarak da sorunların değerlendirilmesi ve öneriler getirilmesidir. Çalışma sonucunda, gıda güvencesinin hanehalkı düzeyinde izlenmesinde en az iki ölçütün kullanılması, global ve ulusal bazda ise gelişmişlik düzeylerine göre farklı ölçütlerin ve ağırlıkların belirlenmesi önerilmektedir.

Anahtar Kelimeler: gıda güvencesi, gıda güvencesi ölçütleri, küresel gıda güvencesi endeksi, gıda güvencesizliği

\section{An Evaluation on Monitoring and Mapping of Food Security}

\begin{abstract}
Ensuring food security is one of the main global targets. In order to achieve national and international goals by analyzing the current situation and determine policies, it is utmost important to monitoring and mapping of food security. Recently, national and international organizations aim for setting dimensions to reveal the current situation of food security and to monitor and map through information networks. However, a globally accepted and reliable standard has not been established yet and discussions are still ongoing. In this context, this study has three main objectives; the first one is to classify the methods that used to monitoring dimensions of food security, the second one is to present the reviews for each dimension and discuss the results of the scientific research, finally to evaluate the problems and to put forward recommendations. As a result of the study, it is recommended to address at least two dimensions of the food security at the household level and to determine different criteria and weight for monitoring at the global and country level.
\end{abstract}

Keywords: food security, dimensions of food security, global food security index, food insecurity

\section{GíRiş}

Gıda güvencesinin sağlanması, küresel olarak tartışılan önemli konuların başında gelmektedir. Ancak, artan nüfus ve değişen tüketim alışkanlıkları, çevre sorunları ve iklim değişikliği, politik sorunlar ve enerji ihtiyacının karşılanması için tarım ve gıda ürünlerinin kullanılması nedeniyle küresel gıda güvencesi tehdit altındadır.

Gıda güvencesinin izlenmesi ve bu kapsamda da mevcut durumun ortaya konarak müdahale ihtiyacının belirlenmesi, verilerin ve bilgilerin erişilebilir olmasının sağlanması ve ulusal gıda ve tarım bilgi sistemlerinin bir parçası haline getirilmesi, karar vericilerin bilgi gereksinimlerinin karşılanması, uluslararası karşılaştırmalar ve iş birlikleri yapılabilmesi, gelecek senaryolarının ve politikaların hazırlanması açısından önemlidir (Babu ve ark., 2014; Uzmay ve ark., 2015; Koç ve Uzmay, 2015). Bu nedenle, mevcut yöntemlerin iyi analiz edilmesi, avantaj ve dezavantajlarının, farklarının ve eleştirilen yönlerinin gıda güvencesinin farklı ölçütleri itibariyle ortaya koyulması gerekmektedir. Bu kapsamda, çalışmanın kapsamlı ana ve yan amaçları aşağıda sıralanmaktadır;

1. Küresel gıda güvencesinin izlenmesi ve haritalanmasında rol oynayan kuruluşların ve bilgi ağlarının belirlenmesi,
2. Gıda güvencesi ölçütlerine göre kullanılan yöntemlerin sınıflandırılması,

3. Her bir ölçüt için bilimsel araştırma sonuçlarının tartışılması,

4. Sorunların değerlendirilmesi ve öneriler getirilmesidir.

Gıda güvencesi izlenme ölçütleri bulunabilirlik, erişilebilirlik, kullanılabilirlik, istikrar olmak üzere dört ölçüt ve son dönemlerde yeni bir ölçüt olarak dahil edilen iklim değişikliği ve doğal kaynaklar ölçütü ele alınarak değerlendirilmiştir.

\section{KÜRESEL GIDA GÜVENCESININ IZLENMESI ve} HARITALANMASI

\section{Gıda Güvencesi Kavramı}

Gıda güvencesi, bütün insanların, her zaman, aktif ve sağlıklı yaşamı için gerekli olan besin ihtiyaçlarını ve gıda önceliklerini karşılayabilmek amacıyla, yeterli, sağııkı, güvenilir ve besleyici gıdaya, fiziksel ve ekonomik bakımdan sürekli erişebilmeleri olarak tanımlanmaktadır (FAO, 2012). Gıda güvencesi, yalnızca gıda mevcudiyetinin eksikliğini,

Sorumlu Yazar: gkc add@hotmail.com Doktora seminerinden türetilmiştir

Geliş Tarihi: 10 Mayıs 2019

Kabul Tarihi: 11 Aralık 2019 
gıdaya erişimi ve gıdaların evde nasıl kullanıldığı değil, aynı zamanda bireylerin gıdaya erişimi üzerindeki belirsizlik, stres ve gıdaların kabul edilebilirliği anlamına da gelen çok boyutlu bir kavramdır.

\section{Gıda güvencesi bilgi ağları ve ilgili kurumlar}

Küresel gıda güvencesinin izlenmesi ve haritalanması sürecinde aktif olarak rol alan kurumlar; Food and Agriculture Organization (FAO), World Food Programme (WFP), International Food Policy Research Institute (IFPRI) gibi uluslararası kuruluşlardır. Ayrıca, Economist Intelligence Unit (EIU), Instutute of Development Studies (IDS) gibi diğer araştırma kurumları da gıda güvencesinin izlenmesinde çalışmalar yapmaktadır.

Illgili kurumlar, gıda güvencesi bilgilerini bir araya getiren, birçok bilim adamının görev aldığı bilgi ağları oluşturmuşlardır. En kapsamlı bilgi ağı; FAO, IFPRI ve WFP tarafından oluşturulan Gıda Güvencesi Bilgi Ağı (Food Security Information Network (FSIN))'dır. FSIN, "gıda güvencesinin izlenmesinde güvenilir ve doğru veriler üretmeye yönelik küresel bir girişim" olarak tanımlanmaktadır. Gıda güvencesi analizlerinde kapasite geliştirmek, raporlar hazırlamak, uzmanlar yetiştirmek ve kurslar düzenlemek, uygulamalar geliştirmek gibi çok farklı amaçları vardır. WFP'nin gıda güvencesi veri görüntüleme platformunda ise ülkelerde açlık analizi, mevsimsel ve ekonomik araştırmalar yapılmakta, ayrıca gıda güvencesizliği bulunan ülkeler için kapsamlı interaktif raporlar sunulmaktadır.

\section{Gıda güvencesi raporları}

Dünyada gıda güvencesi, beslenme ve açlığın durumunu ülkeler ve bölgeler itibariyle ortaya koyan kapsamlı ve önemli bir rapor FAO'nun Dünya'da Gıda Güvencesi ve Beslenme Durumu Raporu'dur (The State of Food Security and Nutrition in the World, (SOFI)) (FAO, 2018a). GIda Güvencesi ve Tarımda Erken Uyarı, Erken Eylem Raporu da FAO tarafından 2016 yılından beri 3 aylık yayınlanmaktadır. Raporun amacı, ülkelerde gıda güvencesine yönelik önemli riskleri ortaya koymak ve etkileri hafifletecek önerilerde bulunmaktır. Raporda, gıda güvencesini tehdit edebilecek her türlü risk yüksek, orta, düşük seviye olarak sınıflandırılarak ortaya koyulmaktadır. Ekonomik ve politik riskler, iklim değişikliği ve anomalileri, bitki ve hayvan hastalıkları raporun başlıca risk alanlarıdır ve bunlara yönelik tavsiyeler sunulmaktadır.

IFPRI tarafından yayınlanan Küresel Gıda Politikaları Raporu (Global Food Policy Report), gıda politikaları ve gıda güvencesi arasındaki ilişkiyi, politik gelişmeleri, küresel gıda güvencesizliği durumunu, tarımsal harcamalar ve araştırma yatırımlarını, tarımsal üretim ve tüketim projeksiyonlarını ele almaktadır. FSIN tarafından yayınlanan Küresel Gıda Krizleri Raporu'nda (Global Report on Food Crisis) ise gıda güvencesizliği şiddetinin ortaya koyulması, gıda krizlerinin sebeplerinin belirlenmesi ve sonraki yıl için projeksiyonlar yapılması konularında kapsamlı değerlendirmeler yer almaktadır.

\section{Gıda güvencesinin izlenmesinde gerekli kriterler}

Gıda güvencesi, çok boyutlu bir kavram olması nedeniyle çeşitli ölçütler ve değişkenler yardımıyla izlenebilmektedir. Gıda güvencesinin sağlanması için tüm ölçütlerin aynı anda gerçekleşmesi gerekmektedir (Niyaz ve İnan, 2016). Gıda güvencesi göstergeleri için belirlenen SMART (spesific, measureable, achievable, relevant, time-bound) kriterleri ise aşağıdaki gibidir (Perez-Escamilla ve ark., 2017);

Spesifik: Göstergeler, açık bir şekilde tanımlanmalı ve sadece ilgili olguyu ölçmelidir,

Ölçülebilir: Göstergeler, güvenilir ve bulunabilir olmalıdır,

Ulaşılabilir: Göstergeler, uygun bir şekilde toplanabilmeli, maliyeti düşük olmalı ve kolaylıkla analiz edilebilmelidir,

Amaca uygun: Karar vericilerin politika tasarımı ile ilgili sorularını cevaplamalıdır,

Zaman sınırlamalı: Uygun bir zaman dilimi içinde toplanmalıdır.

Bu kapsamda, FAO'nun gıda güvencesi veri tabanında bulunabilirlik ölçütü için gıda arzı ve mikro besin kalitesini, erişilebilirlik ölçütü için ülkelerdeki ulaşım altyapısı ve bireylerin ekonomik durumunu, istikrar ölçütünde ülkenin gıda üretimindeki dalgalanmaları ve dış ticareti, kullanılabilirlik boyutunda ise bireylerin sağlık hizmetleri ve suya erişimini, sağlık durumunu konu alan değişkenler yer almaktadır (Çizelge 1).

\section{Bulunabilirlik ölçütü}

Gıda güvencesinin izlenmesindeki ilk ölçüt bulunabilirlik ölçütüdür ve herkes için yeterli gıdanın mevcudiyetini temsil etmektedir. Bulunabilirlik ölçütü; gıda arzı, yeterliliği ve mikro besin kalitesi, gıda kayıpları gibi üretimle ilgili değişkenler ile izlenmektedir (Dağdur ve Olhan, 2015; Koç ve ark., 2018).

Bulunabilirlik ölçütünün izlenmesinde kullanılan en eski ve en yaygın gösterge FAO'nun yetersiz beslenme yaygınlığı (prevalence of undernourishment, PoU) göstergesidir. PoU, günlük enerji gereksinimini karşılamak için gerekli olan asgari miktarda besini tüketemeyen nüfusun oranını göstermektedir (FAO, 2014). 2019 yılı SOFI raporunda yetersiz beslenme yaygınlığının \%10.8 olduğu açıklanmıştır (FAO, 2019a). PoU, gıda güvencesinin izlenmesinde kullanılan en eski yöntemlerden biri olsa da diyet kalitesini ölçememesi, hanehalkı ve yerel düzeyde sonuçlar sunamaması, acil durumların tespitinde kullanılamaması nedeniyle eleştirilmektedir (Keskin ve Demirbaş, 2012; Pangaribowo ve ark., 2013; Babu ve ark., 2014; Cafiero ve ark., 2014; Kakwani ve Son, 2015; Perez-Escamilla ve ark., 2017). 
Çizelge 1. FAO gıda güvencesi göstergeleri

\begin{tabular}{|c|c|}
\hline Ölçüt & Değişkenler \\
\hline Bulunabilirlik & $\begin{array}{l}\text { Günlük diyetteki enerji arzı yeterliliği, ortalama gıda üretimi, günlük diyette hububatlar, köklü ve } \\
\text { yumrulu bitkilerin payı, kişi başına ortalama protein arzı }\end{array}$ \\
\hline Erişilebilirlik & $\begin{array}{l}\text { Demiryolu hatlarının sıklığı, kişi başına gayri safi yurtiçi hasıla, yetersiz beslenme yaygınlığı, şiddetli gıda } \\
\text { güvencesizliği yaygınlığı }\end{array}$ \\
\hline Kullanılabilirlik & $\begin{array}{l}\text { Temel ve güvenli içme suyu ve sağlık hizmetlerine erişim, } 5 \text { yaşın altındaki çocuklarda düşük ağırlık, boy } \\
\text { kısalığı ve obezite oranı, erişkin nüfusta obezite yaygınlığı, üreme çağındaki kadınlarda anemi yaygınlığı, } \\
\text { 0-5 aylık bebeklerde emzirme yaygınlığı }\end{array}$ \\
\hline İstikrar & $\begin{array}{l}\text { Tahıllarda ithalata bağımlılık oranı, sulanabilir arazi varlığı, toplam ihracat içinde gıda ithalatının oranı, } \\
\text { politik istikrar, şiddet ve terör endeksi, kişi başına gıda üretimindeki kararsızlık }\end{array}$ \\
\hline
\end{tabular}

Kaynak: FAO, 2018b.

IFPRI tarafından tasarlanan Küresel Açlık Endeksi (Global Hunger Index (GHI)), dünyada açlığın durumunu ölçmek ve izlemek amacıyla her yıl hesaplanmakta ve 119 ülkeyi kapsamaktadır. Endeks kapsamında her ülke için 9.9 ve altı düşük, 50 ve üzeri çok endişe verici gıda güvencesizliği olmak üzere puan verilmekte ve ülkeler sınıflandırılmaktadır (IFPRI, 2019). Endeks puanlarının hesaplanmasında, ağırlığı eşit olan 3 temel boyuttan ve bu boyutları temsil eden 4 farklı göstergeden yararlanılmaktadır. Bunlar; kalori alımı yetersiz olan nüfusun oranı, 5 yaşın altındaki çocuklarda zayıflık, bodurluk ve ölüm oranıdır. GHI 2019 sonuçlarına göre, 43 ülkede ciddi, 4 ülkede endişe verici açlık olduğu belirlenmiştir. Türkiye'nin puanı 5 'in altında olup puan sıralamasında 1. olan 17 ülkeden biridir (IFPRI, 2019). GHI, göstergelerin ağılıklarının eşit alınması ve göstergeler arasında ilişki bulunabileceği belirtilerek eleştirilmektedir (Masset, 2011). Ayrıca, 5 yaş altı çocuklarda zayıflık ve bodurluk gibi göstergeler yalnızca gıda güvencesizliği nedeniyle değil, genetik faktörler, yetersiz sağlık hizmetleri, anne eğitimi, ailenin durumu, sosyal çevre ile ilgili de olabilir. Endekste beş yaş altı çocuklara yer verilmesi nedeniyle ise nüfusun tamamının temsil edilemediği belirtilmiştir (Jones ve ark., 2013; Aiga, 2015; Bühler ve ark., 2018). Nitekim, Aiga (2015) endeks göstergelerinin gıda güvencesizliğini doğru ölçemediğini, göstergelerin toplam ağırlıklarının \%50 olması gerektiğini belirtmiştir. Çalışmada, ülkelerin GHI skorları yeni ağırlıklar ile tekrar hesaplanmış ve sadece 13 ülkenin puanı iyileşmiştir.

Entegre Gıda Güvencesi Faz Sınıflandırması (The Integrated Food Security Phase Classification (IPC)), gıda güvencesizliğine acil müdahale ihtiyacının belirlenmesi ve karar vericilerin hızlı şekilde bilgilendirilmesini amaçlamakta ve ülkeleri gıda güvencesi durumuna göre sınıflandırmaktadır. IPC, her ülkede analistler yardımıyla gıda güvencesi durumuna ulaşmakta ve en geç 3 aylık verileri kullanmaktadır. Bu kapsamda ülkeler minimal, stres, kriz, acil durum ve kıtlık olmak üzere 5 fazda sınıflandırılmaktadır. IPC'e göre 2018 yılında 53 ülkede 113 milyon kişi kriz seviyesinde ve daha şiddetli gıda güvencesizliği yaşamıştır ve 29 milyonu iklim değişikliğinden kaynaklanmaktadır (FAO, 2019a; IPC, 2019).

Bulunabilirlik ölçütünün izlenmesinde bir başka yöntem ise WFP'nin Savunmasızlık Analizi ve Haritalanması Programı'dır (Vulnarability Analysis and Mapping (VAM)). Programın amacı, gerçek zamanlı ve tecrübelere dayanan gıda güvencesi verileri sunmaktır ve 59 ülkeyi kapsamaktadır. Bu kapsamda, makro veriler ile çalışan diğer yöntemlerin aksine, ülkelerde aylık 20 binden fazla anket yapılmaktadır. Anket sonuçlarına göre, gıda tüketim skorları, yemeğini kısmak zorunda kalan, daha ucuz gıdalar tüketen ve gıda yardımı isteyen nüfusun oranı belirlenmektedir (WFP, 2019).

Kaur ve Kaur (2016) tarafından 53 ülkenin PoU skorları kullanılarak gerçekleştirilen çalışmada, yetersiz beslenme yaygınlığının belirleyicilerinin ortaya koyulması amaçlanmıştır. Araştırma sonuçlarına göre, gıda enflasyonu ve gıda fiyatlarındaki oynaklık gıda güvencesizliğini önemli ölçüde arttırmaktadır. Sibhatu ve Qaim (2018), tarımsal ürün çeşitliliğinin bulunabilirliğin ve diyet çeşitliliğinin önemli bir belirleyicisi olduğunu ortaya koymuştur. Amerika'da ise kent bahçeciliği, bireylerin gıda güvencesi durumlarını iyileştirmiş; meyve ve sebze tüketimi artmış, organik tüketim yaygınlaşmış ve gıda güvenliği iyileşmiş, gıda harcamaları ise azalmıştır (Diekmann ve ark., 2018). Bulunabilirlik ölçütünü tehdit eden en önemli sorunlardan biri ise, üreticilerin tarımsal üretimden vazgeçmeleridir. Nitekim, Koç ve Uzmay (2019) tarafından Trakya Bölgesi'nde, Altıntaş ve ark. (2019) tarafından Orta Karadeniz'de, Çukur (2016) tarafından Milas, Muğla'da gerçekleştirilen çalışmalarda nüfusun beslenme ve gıda ihtiyacının karşılanması, ayrıca tarımsal üretimin sürdürülebilirliğinin sağlanması için üreticilerin tarımda kalma eğilimlerinin arttırılması gerektiğini belirtmiştir.

\section{Erişilebilirlik ölçütü}

Gıda güvencesinin ikinci ölçütü erişilebilirlik olup gıdalara ekonomik ve fiziki erişimi temsil etmektedir. Ekonomik erişilebilirlik, kişi başına gayrisafi yurtiçi hasıla, gıda harcamalarının toplam harcamalar içindeki payı gibi 
değişkenler ile, fiziki erişilebilirlik ise ülkelerin lojistik altyapılarına yönelik değişkenler yoluyla izlenmektedir.

Erişilebilirlik ölçütü, FAO tarafından 2013 yılında tasarlanan şiddetli gıda güvencesizliği yaygınlığı (prevelance of severe food security, $\mathrm{FI}_{\text {sev }}$ ) göstergesi ile izlenmektedir ve gösterge hanehalkı anket verilerine dayanmaktadır. Bu kapsamda, anketlerin gerçekleştirilmesi için gıda güvencesizliği deneyim ölçeği (The Food Insecurity Experience Scale (FIES)) tasarlanmıştır. Ölçek, 200 dil ve lehçeye çevrilmiş olup 153 ülkede uygulanmaktadır (FAO, 2013). Ölçekte yer alan 1., 2. ve 3. sorular hafif, 4., 5., 6. sorular orta dereceli, 7. ve 8. sorular ise şiddetli (açlık boyutunda) gıda güvencesizliğine işaret etmektedir (FAO, 2013) (Çizelge 2).

Çizelge 2. Gıda Güvencesizliği Deneyim Ölçeği (FIES) soruları

\begin{tabular}{l} 
Son 12 ay boyunca, para veya başka kaynakların eksikliğind \\
\hline 1. yeterli gıda bulamayabileceğiniz için kaygılandığınız \\
3. sadece birkaç tür gıda yediğiniz \\
5. yemeniz gerektiğini düşündüğünüzden daha az yediğiniz \\
7. karnınız aç olmasına rağmen yemek yemediğiniz
\end{tabular}

SOFI 2019'da küresel $\mathrm{Fl}_{\text {sev }} \% 9.2$ olarak açıklanmıştır. Bu oran, Afrika'da \%21.5, Asya'da \%7.8, Türkiye'de ise \%5.73'tür (UNICEF, 2017; FAO, 2019a). Son dönemlerde artan sayıda çalışma, ülkelerde FIES ölçeği yardımıyla bireylerin sosyo ekonomik ve demografik özellikleri ile gıda güvencesi arasındaki ilişkiyi araştırmıştır (Smith ve ark., 2017; Depa ve ark., 2018; Asfahani ve ark., 2019). Grimaccia ve Naccarato (2018), 147 ülkenin FIES sonuçlarını ile gerçekleştirdikleri çalışmada, eğitim ve hanehalkı çocuk sayısının gıda güvencesizliği üzerinde önemli bir etkiye sahip olduğu ve bu faktörlerin ülkelerin gelişmişlik düzeyinden bağımsız olduğu ortaya konmuştur. Jones (2017)'un 149 ülkeden 152.7 bin bireyin FIES sonuçları ile sağlık durumları arasındaki ilişkiyi araştırdığı çalışmada, gıda güvencesizliğinin mental sağlık durumunu doğrudan etkilediği ve depresyon riskini arttırdığı belirlenmiştir. Latin Amerika ve Karayipler'de 22 ülkede 17.3 bin kişiyle FIES ölçeği ile yapılan görüşmeler sonucunda ise, gıda güvencesizliği yaşanma olasılığının en önemli belirleyicilerinin düşük eğitim, sınırlı sosyal sermaye ve kişi başına düşen GSYiH'nin düşük olduğu ülkelerde yaşamak olduğu ortaya konmuştur (Smith ve ark., 2017). Asfahani ve ark. (2019) tarafından 19 Arap ülkesinde $15-24$ yaş arası 8 bin genç ile gerçekleştirilen FIES çalışmasının sonuçlarına göre, gençlerin \%14.9'unun orta, \%13.8'inin ise şiddetli gıda güvencesizliği yaşadığı belirlenmiştir. Yüksek politik istikrar riski olan ülkelerde şiddetli gıda güvencesizliği \%32.1, düşük ülkelerde ise \%6.9'dur. Almanya'da 1033 gıda bankası kullanıcısı ile yapılan çalışmada ise, katılımcıların \%30'unun orta ve \%7'sinin şiddetli gıda güvencesizliği yaşadığı, gençler, erkekler ve sigara içenler arasında gıda güvencesizliğinin daha yaygın olduğu belirlenmiştir (Depa ve ark., 2018).

Erişilebilirlik ölçütünün izlenmesinde bir başka yöntem ise WFP'nin gıda güvencesi verileri görüntüleme platformudur. Platformda ülkeler için ekonomik analizler yapılmakta, gıda güvencesi ve fiyatlar arasındaki ilişki araştırılmaktadır. 240
2. sağlıklı ve besleyici gıda yiyemediğiniz
4. bir öğünü atlamak zorunda kaldığınız
6. hanenizdeki gıdaların tükendiği
8. tam bir gün boyunca yemek yemediğiniz

Fiyatlar, gıda güvencesine etkilerine göre stres, alarm ve kriz durumu olmak üzere sınıflandırılmaktadır. Ayrıca, ARMA modelleri yardımıyla fiyat tahminleri yapılarak gıda güvencesine etkileri ortaya koyulmaktadır (WFP, 2019).

Erişilebilirlik ölçütünü makro açıdan inceleyen çalışmalarda, ülkelerin makroekonomik özellikleri ve gıda güvencesi arasındaki ilişki araştırılmaktadır. Bu kapsamda, kişi başı gelir ve döviz kuru ile gıda güvencesi arasında güçlü ilişki olduğu tespit edilmiştir (Applanaidu ve Baharudin, 2014; Woertz, 2017). Mikro ölçekli çalışmalarda ise, Afganistan'da buğday fiyatlarındaki küçük bir artışın bireylerin satın alma gücünü önemli ölçüde etkilediği, protein alımlarını ve diyet kalitesini azalttığı belirlenmiştir (D’Souza ve Jolliffe, 2016). Biyoyakıtların gıda güvencesine küresel etkisini araştıran çalışmada ise, biyoyakıt üretiminin azaltılması halinde 2024 yılında gıda güvencesinin erişilebilirlik anlamında önemli ölçüde iyileşeceği, bitkisel yağ fiyatlarının \%8, tahıl fiyatları \%6.1, buğday fiyatlarının ise \%3.5 azalacağı ortaya konmuştur (Enciso, 2016).

\section{Kullanılabilirlik ölçütü}

Gıda güvencesinin üçüncü ölçütü olan kullanılabilirlik; gıdaların sağlıklı, besleyici ve güvenli olmasını temsil etmektedir. Nitekim, günümüz entansif tarımsal üretim modelinde yoğun olarak kullanılan kimyasallar, gıda güvenliğini ve dolayısıyla gıda güvencesinin kullanılabilirlik ölçütünü tehdit etmekte ve konuyla ilgili tüketici hassasiyeti de artmaktadır (King ve ark., 2017; Öztürk ve Engindeniz, 2018).

Kullanılabilirlik ölçütü, FAO tarafından temel ve güvenli içme suyuna ve sağlık hizmetlerine erişim, 5 yaşın altındaki çocuklarda sağlık durumu, kadınlarda anemi yaygınlığı gibi göstergeler yoluyla izlenmektedir. Literatürde de kullanılabilirlik ölçütünü araştıran çalışmaların bireylerin sağlık durumu ile gıda güvenceleri arasındaki ilişkiyi araştırdığı dikkati çekmektedir (Rezazadeh ve ark., 2017; Dominick ve ark., 2018). İran'da 723 kişi ile gerçekleştirilen çalışmanın sonuçlarına göre, gıda güvencesizliğinin 
depresyon riskini 2.8 kat arttırdığı belirlenmiştir (Rezazadeh ve ark., 2017). Orta Amerika'da 14 eyalette 1265 kişiyi ile gerçekleştirilen çalışmada ise, yemek yeme düzensizliği olan, diyabetli ve anksiyeteli bireylerin gıda güvencesizliğinin arttığı ortaya koyulmuştur (Dominick ve ark., 2018).

\section{İstikrar ölçütü}

İstikrar ölçütü, bulunabilirlik, erişilebilirlik ve kullanılabilirlik ölçütlerinin istikrarlı ve kararlı olması, gıda güvencesinin sürdürülebilirliği olarak tanımlanmaktadır. Bu ölçütün izlenmesinde kullanılan değişkenler ise, sulanabilir arazi varlığı, gıda arzında yaşanan dalgalanmalar, ithalata bağımlılık ve politik istikrarsızlıklardır.

İstikrar ölçütü, Açlığı Azaltma ve Beslenme Taahhüdü Endeksi (Hunger and Nutrition Reduction Commitment Index ( $\mathrm{HANCl})$ ) ile izlenebilmektedir. $\mathrm{HANCl}$, hükümetlerin açlığa veya yetersiz beslenmeye karşı uyguladığı politikaları, öncelikleri ve gelişmeleri izlemekte ve 45 gelişmekte olan ülkeyi kapsamaktadır. $\mathrm{HANCl}$, eşit ağırlığa sahip iki alt endeksten (beslenme ve açlığı azaltma taahhüdü) ve üç temadan oluşmaktadır. Politikalar temasında; hamileler için sağlık hizmetleri ve çocuklar için vitamin takviyesinin varlığı, su ve sanitasyona erişimi olan nüfusun oranı, ulusal beslenme planının varlığı, tarım arazilerine ve yayıma erişim göstergeleri yer almaktadır. Kamu harcamaları teması beslenme, tarım ve sağlık harcamalarını kapsamaktadır. Yasal çerçeve temasında, gıda hakkının anayasada korunması, kadınların tarım arazilerine erişimi ve ekonomik haklardaki eşitliği gibi değişkenler ele alınmaktadır. Endeks kapsamında ülkeler yüksek, orta, düşük ve çok düşük taahhütlü olmak üzere sınıflandırılmaktadır. HANCI 2017 sonuçlarına göre, 45 ülkeden 8'i yüksek ve 17'si çok düşük taahhütlüdür (IDS, 2018).

\section{Doğal kaynaklar ve iklim değişikliği}

Doğal kaynaklar ve iklim değişikliği ölçütü, doğal kaynakların bozulması ve iklim değişikliğinin gıda güvencesi üzerindeki etkilerini konu almaktadır. Son dönemlerde, gıda güvencesinin diğer ölçütlerine ek olarak, ülkelerde yaşanan iklim olaylarının türü ve sıklığı, ekin büyüme sezonundaki değişim, tarımın ve gıda güvencesinin iklime ve kuraklığa duyarlılığı gibi ek göstergeler de yayınlanmaktadır (FAO, 2018a; EIU, 2018).

Çizelge 3. GFSI hesaplama ölçütleri ve göstergeleri

\begin{tabular}{|c|c|}
\hline Ölçüt & Açıklama \\
\hline 1. Erişilebilirlik & üketicilerin gıda satın alabilme gücü, fiyat şokları ka \\
\hline$(\% 40)$ & arşı geliştirilen programların ve politikaların varlığı \\
\hline $\begin{array}{l}\text { 2. Bulunabilirlik } \\
\text { (\%44) }\end{array}$ & $\begin{array}{l}\text { Ülkelerde gıda arzını etkileyen faktörler, arzın kesintiye uğrama riski, gıda üretimini arttırma } \\
\text { kapasitesi, tarımsal üretimi arttırmaya yönelik araştırma faaliyetleri }\end{array}$ \\
\hline $\begin{array}{l}\text { 3. Kalite ve Güvenlik } \\
\text { (\%16) }\end{array}$ & Günlük diyet çeşitliliği, beslenme kalitesi, mikro besin bulunabilirliği, gıda güvenliği \\
\hline $\begin{array}{l}\text { 4. Doğal Kaynaklar ve } \\
\text { Esneklik }\end{array}$ & $\begin{array}{l}\text { Ülkelerin iklim değişikliğinin etkilerine maruz kalma riski, doğal kaynakların risklere karşı } \\
\text { hassasiyeti ve adaptasyon kapasitesi }\end{array}$ \\
\hline
\end{tabular}

FAO'nun Gıda Güvencesi ve Tarımda Erken Uyarı, Erken Eylem Raporu'na göre, 2019 yılı Ekim-Aralık döneminde gıda güvencesi ve tarıma yönelik küresel risklerin Afrika'da kuraklık ve kasırgalar, Asya'da salgın hastalıklar ve kuraklık, Sudan ve Yemen'de çatışmalar, Haiti ve Venezuela'da ekonomik kriz olduğu açıklanmıştır (FAO, 2019b).

Met Office ve WFP tarafından hazırlanan Gıda Güvencesizliği ve İklim Değişikliği Savunmasızlığı Endeksi (The Food Insecurity and Climate Change Vulnerability Index), 3 farklı emisyon ve 3 farklı adaptasyon senaryosunun kombinasyonlarını kullanarak 2050 ve 2080 yılları için gıda güvencesi savunmasızlığı analizleri yapmaktadır. Yüksek emisyon salınımının devam etmesi ve adaptasyon sağlanmaması durumda, 2050 yılında gıda güvencesizliğinin Güney Amerika'da \%20-30, Afrika'da ve Asya'nın bazı bölgelerinde \%30-40, Rusya'da \%6 artacağı belirtilmektedir (Met Office, 2019).

Doğal kaynaklar ve iklim değişikliği ile gıda güvencesi arasındaki ilişkiyi araştıran küresel çalışmalar, 2 derecelik sıcaklık artışının kişi başına kalori alımını 170 kilokalori düşürebileceğini ve \%3.7 küresel refah kaybı olabileceğini ortaya koymuştur (Hasegawa ve ark., 2018; Fujimori ve ark., 2018). Mutegi ve ark. (2018) ise Sahra Altı Afrika'da iklim değişikliğinin toprak üzerindeki etkilerine yönelik entegre mücadelenin hem verimleri \%100-300 arttırabileceğini, hem de çiftçi gelirini arttırması yoluyla gıda güvencesinin iyileştirilmesinde etkili bir yöntem olacağını belirlemiştir.

Gıda Güvencesinin İzlenmesinde Genel ve Çok Boyutlu Yaklaşımlar

Küresel Gıda Güvencesi Endeksi (Global Food Security Index (GFSI)), gıda güvencesinin izlenmesinde yaygın olarak kullanılan, 113 ülkeyi kapsayan ve yıllık olarak hesaplanan çok boyutlu bir endekstir.

Endeksin hesaplanmasında erişilebilirlik, bulunabilirlik, kalite ve güvenlik ölçütlerinde yer alan çeşitli değişkenlerden yararlanılmaktadır (Çizelge 3). Doğal kaynaklar ve esneklik ölçütü ise bir ayarlama faktörü olarak devreye girmektedir. Endeks hesabı sonucunda ülkelere 75 ve üzeri çok iyi performans, 25 ve altı iyileştirilmesi gereken performans olmak üzere puan verilmektedir. GFSI 2018 yılı

Kaynak: EIU, 2018. 
sonuçlarına göre dünya ortalama puanı 58.4'tür. 29 ülke çok iyi, $28^{\prime}$ er ülke iyi, ortalama ve zayıf performansa sahiptir. Türkiye ise 64.1 puan ile 49. sırada yer almaktadır (EIU, 2018). Doğal kaynaklar ölçütünün dahil edilmesiyle ise özellikle Asya, Avusturalya, Afrika'nın bazı bölgeleri ve Amerika'da gıda güvencesi puanının azaldığı dikkati çekmektedir (EIU, 2019). Endekste kullanılan değişkenlerin neden tercih edildiğinin teorik açıdan net olarak ortaya koyulmadığı, kalite ve güvenlik boyutunda sağlık hizmetleri ve sağlık sorunları gibi göstergelerin göz ardı edildiği, göstergelerin ağırlıklarının seçiminde ülkelerin ekonomik durumları ve coğrafi konumlarının da dikkate alınması gerektiği, bazı göstergelerin EIU uzmanları tarafından puanlandırımasının öznel değerlendirmelere neden olabileceği, kayıp verilerin analizinde ve verilerin standardizasyonunda kullanılan yöntemlerin şeffaf olarak açıklanması gerektiği ifade edilmektedir (Pangaribowo ve ark., 2013; Santeramo 2015; Perez-Escamilla ve ark., 2017; Chen ve ark., 2019).

Nitekim, Chen ve ark. (2019) tarafından gerçekleştirilen çalışmada, 110 ülkenin endeks skorları kullanılarak, Hiyerarşik Veri Zarflama Analizi yardımıyla her ülke için farklı endeks ağırlıkları belirlenmiştir. Araştırma bulgularında, gelir seviyesi azaldıkça bulunabilirlik boyutunun daha önemli hale geldiği ortaya koyulmuştur. Bulunabilirlik probleminin ortadan kalktığı gelir seviyesi yüksek ülkelerde ise erişilebilirlik ölçütü önem kazanmaktadır (Chen ve ark., 2019).

\section{SONUÇ}

Gıda güvencesi, tarım ve gıda üretiminde yaşanan gelişmelere rağmen, küresel açıdan güncel bir sorun olmaya devam etmekte ve konuyla ilgili tartışmalar ve çabalar sürmektedir.

Gıda güvencesinin izlenmesi ve haritalanması ile ilgili artan kurumlar ve hesaplama yöntemlerine rağmen, henüz küresel olarak kabul gören ve güvenilir tam bir standart oluşturulamamıştır. Bu kapsamda, gelişmiş ve gelişmekte olan ülkeler ve bölgelere göre indekslerin ağılıklandırılmasıyla ilgili kapsamlı ve ilgili tüm bilim dallarının yer aldığı multidispliner çalışmalara ihtiyaç bulunmaktadır. Gıda güvencesinin hanehalkı düzeyinde izlenmesinde en az iki ölçütün kullanılması genel kabul görmektedir ve son derece önemlidir. Özellikle bulunabilirlik ve erişilebilirlik ölçütlerine öncelik verilmelidir. Böylelikle hane halklarının ihtiyaçlarının belirlenmesinde doğru değerlendirmeler yapılabilmesi ve sorun çözmeye yönelik politika araçlarının uygulanması mümkün olacaktır. Ulusal düzeyde ise, ülkelerin gelişmişlik ve gelir düzeylerine göre farklı ölçütlerin ve ağırlıkların belirlenmesi gerekmektedir. Az gelişmiş ülkelerde, bulunabilirlik ölçütünün iyileştirilmesine yönelik ürün çeşitlendirilmesi, tarımın doğal koşullara bağlılığının azaltılması ve erken uyarı sistemleri geliştirilmesi, tarımsal sulama ve genel altyapı yatırımları ile tarımsal AR\&GE yatırımlarının arttırılması, kırsal kalkınma yatırımlarına ağırlık verilmesi öncelikli alınması gereken tedbirler arasındadır. Gelişmiş ülkelerde ise, erişilebilirlik ve kullanılabilirlik ölçütü ile ilgili problemler ön plana çıkmaktadır. Bu kapsamda, hem gelişmiş hem de gelişmekte olan ülkelerde gıdanın adil dağılımının sağlanması, gıda güvencesizliği kaynaklı hastalıkların azaltılması, sağlık ve gıda güvenliği yatırımları önem kazanmaktadır.

\section{KAYNAKLAR}

Aiga H (2015) Hunger Measurement Complexity: Is the Global Hunger Index Reliable?. Public Health 129: 1288-1290.

Altıntaş G, Altıntaş A, Bektaş H, Çakmak E, Oruç E, Kızılaslan H, Birol D (2019) Effects of Young Farmer Project Support on The Tendency of Young Farmers to Stay in Agriculture: Case of TR83 Region. Turkey. Turkish Journal of Agriculture-Food Science and Technology 7: 1682-1693.

Applanaidu SD, Baharudin AH (2014) An Econometric Analysis of Food Security and Related Macroeconomic Variables in Malaysia: A Vector Autoregressive Approach (VAR). International Agribusiness Marketing Conference Procedia, 22-23 October 2014, Malaysia, 93-102.

Asfahani F, Kadiyala S, Ghattas H (2019) Food Insecurity and Subjective Wellbeing Among Arab Youth Living in Varying Contexts of Political Instability. Journal of Adolescent Health 64: 70-78.

Babu S, Gajanan SN, Sanyal P (2014) Food Security, Poverty and Nutrition Policy Analysis: Statistical Methods and Applications. Academic Press, USA.

Bühler D, Hartje R, Grote U (2018) Matching Food Security and Malnutrition Indicators: Evidence from Southeast Asia. Agricultural Economics 49: 481-495.

Chen PC, Yu MM, Shih JC, Chang CC, Hsu SH (2019) A Reassessment of the Global Food Security Index by Using a Hierarchical Data Envelopment Analysis Approach. European Journal of Operational Research 272: 687-698.

Cafiero C, Melgar-Quiñonez HR, Ballard TJ, Kepple A W 2014 Validity and reliability of food security measures. Annals of the New York Academy of Sciences 1331: 230-248.

Çukur T (2016) Milas İlçesinde Süt Sığırcılığı Yapan Çiftçilerin Tarımda Kalma Eğilimlerinin Belirlenmesi. 12. Ulusal Tarım Ekonomisi Kongresi, 25-27 Mayıs 2016, Isparta, 1235-1244.

Dağdur E, Olhan E (2015) Küresel Gıda Güvencesi Endeksi Kapsamında Türkiye'nin Değerlendirilmesi. Tarım Ekonomisi Dergisi 21: 49-61.

D'Souza A, Jolliffe D (2016) Coping with Food Price Shocks in Afghanistan. In: Food Price Volatility and Its 
Implications for Food Security and Policy, Springer Publishing, Bonn, 543-581.

Depa J, Gyngell F, Müller A, Eleraky L, Hilzendegen C, Stroebele-Benschop N (2018) Prevalence of Food Insecurity Among Food Bank Users in Germany and Its Association with Population Characteristics. Preventive Medicine Reports 9: 96-101.

Diekmann LO, Gray LC, Baker GA (2018) Growing 'Good Food': Urban Gardens, Culturally Acceptable Produce and Food Security. Renewable Agriculture and Food Systems 1-13.

Dominick SR, Widmar NJO, Ruple A, Weir JZG, Acharya L, (2018) The Intersection of Food Insecure Populations in the Midwest US and Rates of Chronic Health Conditions. Agriculture and Food Security 7: 1-18.

Economic Intelligence Unit (EIU) (2018) Global Food Security Index 2018: Building Resilience in the Face of Rising Food Security Risks.

Economic Intelligence Unit (EIU) (2019) Global Food Security Index Natural Resources \& Resilience Rankings. www.foodsecurityindex.eiu.com (Erişim Tarihi: 05/01/2019).

Enciso SRA, Fellmann T, Dominguez IP, Santini F (2016) Abolishing Biofuel Policies Possible Impacts on Agricultural Price Levels. Price Variability and Global Food Security. Food Policy 61: 9-26.

FAO (2012) The State of Food Insecurity in the World. Rome.

FAO (2013) The Food Insecurity Experience Scale Development of a Global Standard for Monitoring Hunger Worldwide. FAO Technical Paper Version 1.1, Rome.

FAO (2014) Refinements to the FAO Methodology for Estimating the Prevalence of Undernourishment Indicator. ESS Working Paper 14-05, Rome.

FAO (2018a) The State of Food Security and Nutrition in the World. Rome.

FAO (2018b) Food Security Methodology. http://www.fao.org/economic/ess/ess-fs/fsmet hods/fs-methods1/en/ (Erişim Tarihi: 29/12/2018)

FAO (2019a) The State of Food Security and Nutrition in the World. Rome.

FAO (2019b) Early Warning Early Action Report on Food Security and Agriculture. Rome.

Fujimori S, Hasegawa T, Rogelj J, Su X, Havlik P, Krey V, Riahi K (2018) Inclusive Climate Change Mitigation and Food Security Policy Under $1.5^{\circ} \mathrm{C}$ Climate Goal. Environmental Research Letters 13: 1-11.

Grimaccia E, Naccarato A (2018) Food Insecurity Individual Experience: A Comparison of Economic and Social Characteristics of the Most Vulnerable Groups in the World. Social Indicators Research 1: 391-410.

Hasegawa T, Fujimori S, Havlík P, Valin H, Bodirsky BL, Doelman JC, Mason-D'Croz D (2018) Risk of Increased Food Insecurity Under Stringent Global Climate Change Mitigation Policy. Nature Climate Change 8: 699-703.
KOÇ G, UZMAY A

Institute of Development Studies (IDS) (2018) HANCI Global 2017 www.hancindex. org/hanci/ (Erişim Tarihi: 25/12/2018).

International Food Policy Research Institute (IFPRI) (2019) Global Hunger Index 2019: The challenge of hunger and climate change. Dublin and Bonn.

Jones AD (2017) Food Insecurity and Mental Health Status: A Global Analysis of 149 Countries. American Journal of Preventive Medicine 53: 264-273.

Jones AD, Ngure FM, Pelto G, Young SL (2013) What Are We Assessing When We Measure Food Security? A Compendium and Review of Current Metrics. Advances in Nutrition 4: 481-505.

Kakwani N, Son HH (2015) Measuring Food Insecurity: Global Estimates, Society for the Study of Economic Inequality. Working Paper No: 370.

Kaur S, Kaur H (2016) Determinants of Food Security in SubSaharan Africa, South Asia and Latin America. In: Global Economic Cooperation Views from G20 Countries, Springer, 81-102.

Keskin B, Demirbaş N (2012) Gıda Güvencesi ve Hesaplama Yöntemleri Üzerine Bir Değerlendirme: Kısıtlar ve Öneriler. 10. Ulusal Tarım Ekonomisi Kongresi, 5-7 Eylül 2012, Konya, 900-908.

King T, Cole M, Farber JM, Eisenbrand G, Zabaras D, Fox EM, Hill JP (2017) Food Safety for Food Security: Relationship Between Global Megatrends and Developments in Food Safety. Trends in Food Science and Technology 68: 160-175.

Koç G, Uzmay A (2015) Gıda Güvencesi ve Gıda Güvenligi: Kavramsal Çerçeve, Gelişmeler ve Türkiye. Tarım Ekonomisi Dergisi 21: 39-48.

Koç G, Uzmay A (2019) Trakya Bölgesi Üretcilerinin Süt Sığırcılığı Faaliyetinden Vazgeçme Olasılığını Etkileyen Faktörler. Tarım Ekonomisi Dergisi 25: 41-52.

Koç G, Uzmay A, Çınar G (2018) Gıda Güvencesini Hesaplama Yöntemleri ve Son Gelişmeler. IX. IBANESS Kongreler Serisi, 29-30 Eylül, Edirne, 967-979.

Masset, E (2011) A Review of Hunger Indices and Methods to Monitor Country Commitment to Fighting Hunger. Food Policy 36: 102-108.

Met Office (2019) Food Insecurity and Climate Change Index. www.metoffice. gov.uk/food-insecurity-index/ (Erişim Tarihi: 03/01/2019)

Mutegi J, Ameru J, Harawa R, Kiwia A, Njue A (2018) Soil Health and Climate Change: Implications for Food Security in Sub-Saharan Africa. International Journal of Development and Sustainability 7: 21-33.

Niyaz ÖC, İnan H (2016) Türkiye'de Gıda Güvencesinin Mevcut Durumunun Değerlendirilmesi. Adnan Menderes Üniversitesi Ziraat Fakültesi Dergisi 13: 1-7.

Öztürk G, Engindeniz S (2018) Muğla'da Örtüaltı Domates Üretiminde Girdi Kullanım Etkinliğinin Analizi. Tarım Ekonomisi Dergisi 24: 175-183.

Pangaribowo EH, Gerber N, Torero M (2013) Food and Nutrition Security Indicators: A Review. Working Paper Series No.108, Center for Development Research (ZEF), Bonn. 
Pérez-Escamilla R, Gubert MB, Rogers B, Hromi-Fiedler A (2017) Food Security Measurement and Governance: Assessment of the Usefulness of Diverse Food Insecurity Indicators for Policy Makers. Global Food Security 14: 96-104.

Rezazadeh A, Omidvar N, Eini-Zinab H (201) The Association Between Food Security Status and Depression in Two Iranian Ethnic Groups Living in Northwest of Iran. International Journal of Biological, Biomolecular, Agricultural, Food and Biotechnological Engineering 11: 600-605.

Santeramo FG (2015) On the Composite Indicators for Food Security: Decisions Matter!. Food Reviews International 31: 63-73.

Sibhatu KT, Qaim M (2018) Farm Production Diversity and Dietary Quality: Linkages and Measurement Issues. Food Security 10: 47-59.

Smith MD, Kassa W, Winters P (2017) Assessing Food Insecurity in Latin America and the Caribbean Using
FAO's Food Insecurity Experience Scale. Food Policy 71: 48-61.

The Integrated Food Security Phase Classification (IPC) (2019) www.ipcinfo.org (Erişim Tarihi: 05/01/2019).

United Nations International Children's Emergency Fund (UNICEF) (2017) Prevalence and Correlates of Food Insecurity Among Children Across the Globe. Florence.

Uzmay A, Yercan M, Doğan ZA (2015) Assessment of Food Security in the World and Turkey. Works of the Faculty of Agriculture and Food Sciences, University of Sarajevo, 61: 458-462.

Woertz E (2017) Food Security in Iraq: Results from Quantitative and Qualitative Surveys. Food Security 9: 511-522.

World Food Program (WFP) (2019) Food Security Analysis. www.wfp.org/food-security-analysis (Erişim Tarihi: 02/01/2019). 